\title{
Mantle Cell Lymphoma
}

\author{
Noel Milpied and Martin Dreyling
}

Mantle cell lymphoma is a distinct lymphoma subtype with a widely varying clinical course. Established high-risk biological factors include blastoid cytomorphology, high cell proliferation (Ki-67 > 67\%), and p53 mutations (Aukema et al. 2018). While current first-line approaches are still chemotherapy-based, BTK inhibitors are the preferred targeted approach, especially in early relapse cases (POD24) (Dreyling et al. 2017; Visco et al. 2021). However, cases of relapse/progression under BTK inhibitors display extremely aggressive features with a dismal outcome after conventional regimens (Martin et al. 2016).

\section{Clinical Indications for CAR-T Cells}

Following a conditional marketing authorization issued by the EMA in December 2020, Tecartus ${ }^{\circledR}$ (Gilead) is the first autologous anti-CD-19 CAR-T cell therapy that can be administered to patients with mantle cell lymphoma in Europe. Patients deemed eligible for this treatment are those with histologically verified mantle cell lymphoma resistant to or relapsing after two or more lines of treatment, including a Bruton tyrosine kinase (BTK) inhibitor.

This registration is based on the results of recently reported a multicentre phase 2 trial (Wang et al. 2020a). Briefly, 74 patients with a median age of 65 (38-79) were enrolled, and $88 \%$ were refractory to or relapsed after BTK inhibitor treatment at any time point. The CAR-T cell product could be manufactured for 71 , and 68

\footnotetext{
N. Milpied

Department of Hematology and Stem Cell Transplantation, Centre Hospitalier Universitaire, Bordeaux, France

e-mail: noel.milpied@chru-bordeaux.fr

M. Dreyling $(\bowtie)$

Department of Medicine III, LMU Hospital, Munich, Germany

e-mail: martin.dreyling@med.uni-muenchen.de 
Table 13.1 Updated response rates (Wang et al. 2020b)

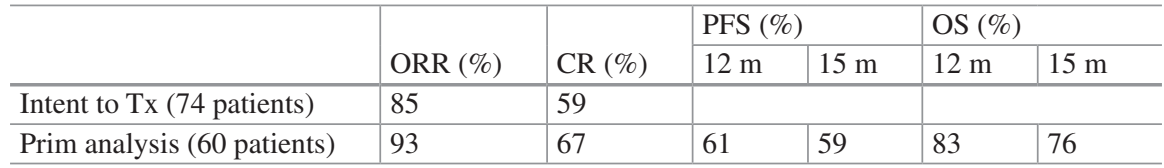

received $2 \times 10^{6} \mathrm{CAR}-\mathrm{T}$ cells/ $\mathrm{kg}$ on Day 0 after a conditioning regimen consisting of fludarabine $\left(30 \mathrm{mg} / \mathrm{m}^{2} /\right.$ day $)$ and cyclophosphamide $\left(500 \mathrm{mg} / \mathrm{m}^{2} /\right.$ day $)$ from Day 5 to Day 3. The overall response rate of all 74 patients (intent-to-treat population) was $85 \%$, with a CR rate of 59\%. More importantly, after 15 months, $59 \%$ of the 60 evaluable patients were still in remission (Wang et al. 2020b) (Table 13.1).

Interestingly, in contrast to conventional strategies, the percentages of patients with an objective response were consistent among key subgroups, including patients with high-risk features (Wang et al. 2020a).

Adverse events were mainly cytopenias ( $\geq$ grade 3: 94\%) and infections $(\geq$ grade 3:32\%). A total of $26 \%$ of the patients had grade 3 or higher cytopenias more than 90 days after the administration of KTE-X19, including neutropenia (in 16\% of patients), thrombocytopenia (16\%), and anaemia (12\%).

These encouraging results have also been confirmed for another CAR-T cell construct (Lisocabtagene Maraleucel; Palomba et al. 2020).

\section{Critical Evaluation}

These excellent results were achieved in the context of a prospective study in highly selected patients. Recently similar results have been reported in a "real life setting" (Wang et al. 2021).

In the current algorithm of the approved indication, several other conditions must be fulfilled before implementation of this treatment: careful work-up of the patient, an experienced interdisciplinary team, and a specialized hospital with follow-up resources. In future trials, the benefit-risk ratio of this demanding treatment will be rechallenged in earlier treatment lines.

\section{Key Points}

- Patients with relapsed MCL progressing under the BTK inhibitor ibrutinib should be considered for CD19 CAR-T cell therapy.

- Effective lymphodepleting chemotherapy is needed to allow expansion of CAR-T cells. 


\section{References}

Aukema SM, Hoster E, Rosenwald A, et al. Expression of TP53 is associated with the outcome of MCL independent of MIPI and Ki-67 in trials of the European MCL Network. Blood. 2018;131(4):417-20.

Dreyling M, Campo E, Hermine O, et al. Newly diagnosed and relapsed mantle cell lymphoma: ESMO clinical practice guidelines for diagnosis, treatment and follow-up. Ann Oncol. 2017;28(Suppl_4):iv62-71.

Martin P, Maddocks K, Leonard JP, et al. Postibrutinib outcomes in patients with mantle cell lymphoma. Blood. 2016;127(12):1559-63.

Palomba ML, Gordon LI, Siddiqi T, et al. Safety and preliminary efficacy in patients with relapsed/ refractory mantle cell lymphoma receiving Lisocabtagene Maraleucel in TRANSCEND NHL 001. ASH; 2020, \#118.

Visco C, Di Rocco A, Evangelista A, et al. Outcomes in first relapsed-refractory younger patients with mantle cell lymphoma: results from the MANTLE-FIRST study. Leukemia. 2021;35(3):787-95.

Wang M, Munoz J, Goy A, et al. KTE-X19 CAR-T cell therapy in relapsed or refractory mantlecell lymphoma. N Engl J Med. 2020a;382:1331-42.

Wang M, Munoz J, Goy A, et al. One-year follow-up of ZUMA-2, the multicenter, registrational study of KTE-X19 in patients with relapsed/refractory mantle cell lymphoma. ASH; 2020b, \#1120.

Wang Y, Jain P, Locke FL, et al. Brexucabtagene autoleucel for relapsed/refractory mantle cell lymphoma: real world experience from the US lymphoma CAR T consortium. ASH 2021, \#744.

Open Access This chapter is licensed under the terms of the Creative Commons Attribution 4.0 International License (http://creativecommons.org/licenses/by/4.0/), which permits use, sharing, adaptation, distribution and reproduction in any medium or format, as long as you give appropriate credit to the original author(s) and the source, provide a link to the Creative Commons license and indicate if changes were made.

The images or other third party material in this chapter are included in the chapter's Creative Commons license, unless indicated otherwise in a credit line to the material. If material is not included in the chapter's Creative Commons license and your intended use is not permitted by statutory regulation or exceeds the permitted use, you will need to obtain permission directly from the copyright holder.

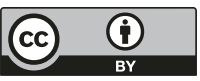

